\title{
Innovation and Practicality
}

\section{An interview with Dr Ken Ryba}

\author{
Dr Jean Annan \\ Senior Lecturer, Massey University, Albany, Auckland
}

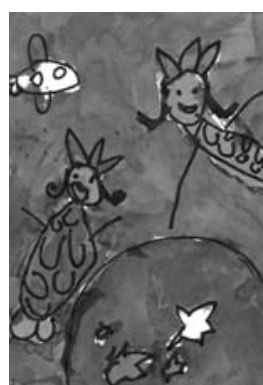

Associate Professor Ken Ryba

Coordinator, Online Professional Diploma in Applied Psychology,

Division of Applied Psychology, University of Calgary, Calgary, Alberta, Canada

\section{INTRODUCING KEN RYBA}

Ken Ryba came to New Zealand from Canada in 1978 to teach special education courses and to work on his PhD at Massey University. His PhD was in the area of computer assisted instruction and he set up the first course on the subject ever to be offered at a New Zealand university. Over the years he has written scores of articles on special education and computers in education. He has also carried out research projects and published extensively on a range of subjects in educational psychology and special education. Ken was instrumental in setting up the Master of Education (Special Education) degree at Massey University. Following this, he spent two years at the University of Waikato in the School of Education developing a new Master of Special Education degree. With the establishment of the new Massey University Albany Campus, he was re-appointed by Massey University and subsequently took the initiative to establish a Master of Educational Psychology and a Post Graduate Diploma in Educational Psychology which leads students toward their registration as psychologists.

\section{INTERVIEW}

\section{J: Ken, what are you doing now?}

K: I am working on a contract at the University of Calgary developing a new online Professional Diploma in Inclusive and Special Education. This is a post-graduate programme for teachers who want to develop their knowledge and skills in teaching students with diverse needs and abilities. The programme is flexibly delivered online using real-time class meetings via web conferencing along with a class website and audioenhanced PowerPoint presentations that are sent out to students. We have students up in the Canadian Arctic in isolated places in Nunavut, North West Territories, British Columbia, Alberta and Saskatchewan. The Professional Diploma can be used as a stand alone qualification or as a stepping stone to masters level. ${ }^{1}$

J: In the first edition of Kairaranga, you commented that today's diverse and complex schools required on-site support from professionals with advanced training. What are your current thoughts?

\footnotetext{
If you would like more information or to see a presentation on the new programme,

go to our website http://www.education.ucalgary.ca/apsy
}

K: I have strongly supported the Resource Teachers: Learning and Behaviour (RTLB) initiative from the time it was proposed in 1995 because it provides the kind of on-site support that teachers need to provide quality education for students with diverse needs. Having been overseas for a year or so now, I can say that the RTLB school-based approach is "the way to go" in terms of providing direct and indirect support for teachers. It is pleasing to me that several of our educational psychology graduates have continued to work as RTLBs, often in senior positions as cluster leaders. This was part of my original thinking about a career pathway in which we could locate special education and school psychology support within educational settings rather than offering a specialist service model. There is widespread concern amongst Canadian schools about the specialist school psychology model in which professionals are based away from the schools. It seems to me that the goal of building capacity in schools to meet the needs of students with diverse needs and abilities requires that we build teams that are located and work directly within the environments where the students, teachers, parents and significant other people are located. I know that there are many reasons advanced for the separation of specialist services from schools in order to provide an independent and fair service. However, to my way of thinking, if we are serious about ecological ways of working then we need to have ecologically sound models of professional support. That means that on-site support should be provided from professionals with advanced training.

\section{J: You created career pathways for many people.} Can you tell us a little about these?

K: I have always tried to maintain a practical orientation whether it was teachers returning to the workforce or people who wanted to do advanced professional training right up to doctoral level. I was modestly successful in providing career opportunities for many people through the development of our Master of Education (Special Education) programmes and also through the establishment of the educational psychology training programme. Unfortunately, I never realised my 
goal of training RTLBs and creating a pathway for the creation of RTLB school psychologists. Having said that, several RTLBs over the years completed educational psychology training at Massey University and have gone on to take leadership roles in special education. It makes me happy to see the success of many of our graduates and the part that they are now playing in special education, educational psychology and allied professional bodies. My greatest satisfaction was to establish a staircase at Massey University so that students with an undergraduate degree in education could move right through their post-graduate certificate, diploma and masters level to doctoral studies.

J: Ken, you were working with computers long before many of us knew they existed! What is exciting about computers?

K: This is a big subject. My initial interest in computers in education was spawned by the belief that the technology could be used to create better learning conditions. My early research with young adults at $\mathrm{IHC}^{2}$ showed how capable these students could be when given access to learning opportunities that they had not previously had. Being a pioneering type, I was keen to be innovative and excited about the prospect of applying this new technology to training and education. I completed my $\mathrm{PhD}$ on the subject of computer-assisted instruction for teaching word recognition to adults with intellectual disability. This was in 1980 and, ironically, I had to type my thesis as we did not yet have a viable word processor. This work set the stage for everything that followed in terms of developing new courses on computers in education, carrying out a range of research projects, and ultimately writing books on the subject of information technology in education. In the 1980s I developed the undergraduate and graduate level courses on computers and the learning process, then, as the technology advanced, I sought new opportunities to create better learning conditions for students with special needs and abilities. It was always the case that each time I began to lose interest in information and communication technology in education there would be a new development and new inventions that created new and exciting research opportunities. I always found the field of computers in education to be extremely positive and uplifting. It enabled me to work with keen people and motivated students to see how we could enhance the teaching and learning process. There has always been a lot of debate about the "effects" of new educational technologies on teaching and learning. Suffice it to say that the machine effects may not be so important as the people effects. It has been a pleasure to see what motivated and capable people can achieve given the right kinds of technology and the right kinds of knowledge about cognition, learning and academic achievement.

\section{J: So, your appreciation of this technology to improve educational conditions has led to some valuable projects. Can you tell us about some of these?}

K: I could say a lot about this but will just sketch a few outlines. $^{3}$ My initial work with computers in education took place in Palmerston North at the IHC sheltered workshop. The focus of this was on computer-assisted instruction for teaching practical academic skills such as counting, time-telling, basic word reading, etc. I subsequently graduated to the prison and to work experience classes where we did projects with youth in transition from school to work. An exciting part of this was to see students who were "at risk" make significant gains in their learning with computers.

I then started to write books and articles with a focus on effective learning strategies with computers. A lot of this work stressed the importance of computers for developing thinking skills and learning strategies. We placed a great deal of emphasis on metacognitive development and "constructivist" approaches to learning. I was greatly influenced by the writing of Seymour Papert concerning children, computers and powerful ideas. Papert's ideas about accelerating cognitive development through the creation of highly interactive and rich learning environments captured my attention. I was keen on the idea that technology provided an intellectual partnership with students who could advance in their learning through interaction with computers and one another. This led me to propose many ideas about the creation of learning communities supported by new educational technologies.

In more recent years I have been actively involved in carrying out projects with teams of colleagues in clusters of schools to study the innovative uses of computers for supporting the teaching and learning process. This included the North Shore Schools Net, the South Auckland Schools Net (both supported by the Tindall Foundation) and Project Activate (supported by the Ministry of Education, Digital Opportunities Project). The outcomes of these projects are recorded in three special issues of the Computers in New Zealand Schools Journal. ${ }^{4}$ All of these projects involved the use of action research in which teachers and schools carried out their own projects to study different aspects of technology for learning. These projects ranged from interactive whiteboards as a context for teaching Te Reo right through to monitoring and recording student health and fitness. All together, our work on these projects has involved teachers in more than 30 schools. It has been especially satisfying to see these teachers publish the results of their projects and to see them present their findings at educational technology conferences and teacher professional development workshops. 


\section{J: What is the highlight of your career to date?}

$\mathrm{K}$ : The highlight of my career to date is the satisfaction of working with so many dedicated and capable people. I have often said that if I can have a positive influence on the professional development of just one other person, then it makes my academic career worthwhile. It brings me great pleasure to see the achievements of so many of our past students and to watch the growth of teachers through our research and demonstration projects. Where new educational technologies are concerned, I feel that I have succeeded in translating theory and research into practice. The sort of applied research that we did created a lot of synergy amongst many people who went on to touch the lives and make a positive difference for the growth and academic achievement of many students. A high point in my career was to establish a flexible high quality educational psychology training programme. This is evident in the large number of graduates from our programme who are now located throughout New Zealand. It would not have been possible for me to achieve anything without being part of a capable and wonderful team, especially my colleagues Jean Annan and Mandia Mentis at the Albany Campus who pioneered the development of our new programmes.

\section{J: What keeps you working in Special Education?}

$\mathrm{K}$ : The work is never done and there is always a need for creation of new ways and new methods of providing quality education for students with diverse abilities and needs. It is rewarding when it happens to make a positive difference in the lives of students and to watch them grow up into capable people. I see it as my responsibility to leave the world a better place than it was when I found it and this is one way that I can make a contribution.

\section{FURTHER READING}

North Shore Schools Net (NSSNet). (2002). An ICT community building approach. Computers in New Zealand Schools, 14(3), 5-8.

Ryba, K., Edwards, T., Duncan, W., \& Dysart, B. (2005). Project ACTIVate: Analysing the effects of teaching and learning with interactive whiteboards. Computers in New Zealand Schools, 17(3), 7-10.

South Auckland Schools Net (SAS-NET). (2003). A unified approach to learning wit ICT. Computers in New Zealand Schools, 15(3), 3-6.

\section{INTERVIEWEE PROFILE}

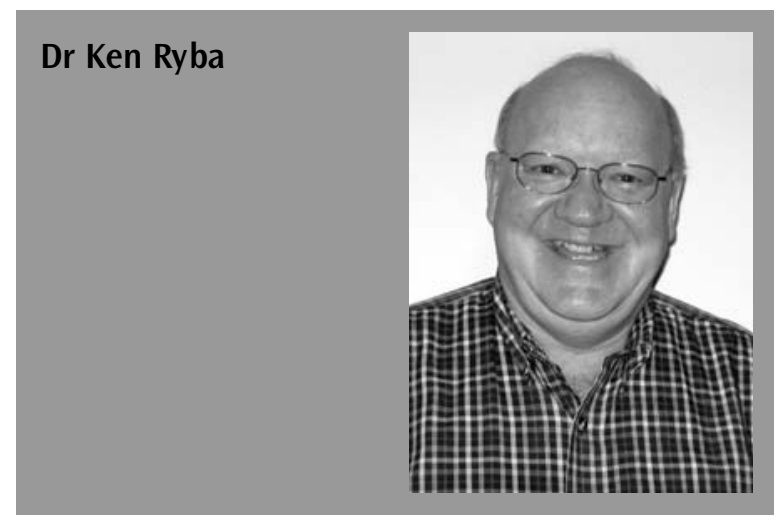

\section{Dr Ken Ryba}

Dr Ken Ryba is currently working at the University of Calgary in his home city. He is the programme coordinator of a new online Postgraduate Diploma in Applied Psychology: Inclusive and Special Education. As a registered psychologist working in New Zealand at Massey and Waikato universities, he established courses in special education and educational psychology. His research background spans general education, special education, educational psychology and the use of information technology in education.

\section{Email}

karyba@ucalgary.ca

\section{INTERVIEWER PROFILE}

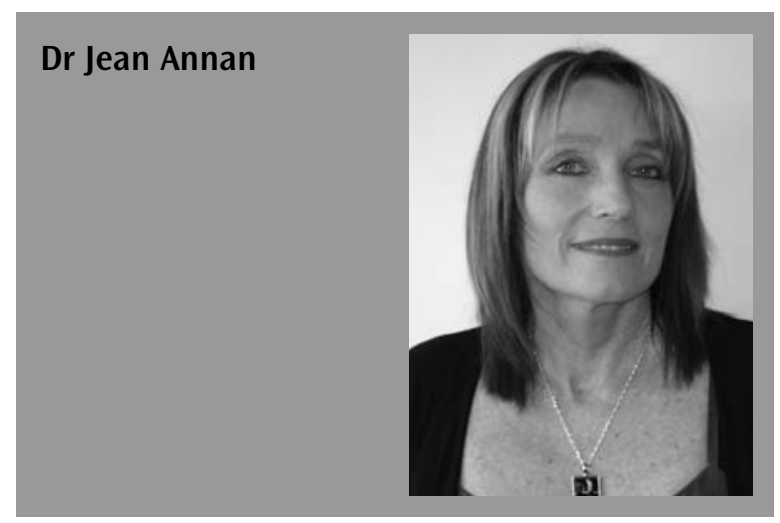

\section{Dr Jean Annan}

Dr Jean Annan is a senior lecturer at Massey University's Auckland Campus in Albany where she coordinates the internship of the Educational Psychology Programme. Jean has a background of experience working in schools as a teacher and as an educational psychologist. Her current research is in educational psychology practice and the development of effective consultation processes.

Email

J.Annan@massey.ac.nz 